ISSN: 1991-2951 (Print)
ISSN: 2091-2781 (Online)
$\begin{gathered}\text { Nature Conservation \& } \\ \text { Bealith Care Council } \\ \text { Birnagar, Nepal }\end{gathered}$

\title{
Fish diversity of Triyuga River, Udayapur District, Nepal
}

\author{
Jay Narayan Shrestha \\ Department of Zoology, Post Graduate Campus, Biratnagar, Tribhuvan University, Nepal \\ E-mail: jaynstha@gmail.com
}

\begin{abstract}
The present paper deals with a synopsis of 48 fish species under 35 genera belonging to 17 families and 6 orders from Triyuga River. Some interesting fish species reported from this river are Barilus shacra, Garra annandalei, Psilorhynchoides pseudecheneis, Badis badis, Olyra longicoudata, Tor putitora, Labeo dero and Anguilla bengalensis. Fish diversity of Triyuga river is rich, thus further extensive study is essential for their conservation.
\end{abstract}

Key words: Barilus shacra, Fish, Fattehpur, Mahabharat hill

DOI: http://dx.doi.org/10.3126/on.v14i1.16452

Manuscript details: Received: 28.08.2016 / Accepted: 25.11.2016

Citation: Shrestha, J.N. 2016. Fish diversity of Triyuga River, Udayapur District, Nepal. Our Nature 14(1):124-134. DOI: http://dx.doi.org/10.3126/on.v14i1.16452

Copyright: ๑ Shrestha 2016. Creative Commons Attribution-NonCommercial 4.0 International License.

\section{Introduction}

Udayapur district $\left(26^{\circ} 39^{\prime}-27^{\circ} 22^{\prime} \mathrm{N}\right.$ and $86^{\circ} 9^{\prime}-87^{\circ} 10^{\prime} \mathrm{E}$ ) is located in the eastern development region of Nepal. It is bounded by nine districts,Dhankuta and Sunsari in the east, Saptari and Siraha in the south, Dhanusa and Sindhuli in the west, Okhaldunga, Khotang and Bhojpur in the north. Triyuga River is one of the major rivers of the district (Fig. 1). It takes its origin from Rautahapokhari which is situated in Okhreni $(2110 \mathrm{~m})$ on the lap of Mahabharat hill.
Initially two small streams, in the form of drainage of the lake, take their form from two separate spots of the lake and both of them run down towards the south slope then confluence and become the river Triyuga. The river receives water from the several streams viz., Babiya, Lohale, Kalikhola, Duwar etc. on its way to the plain. Ultimately it flows to the Saptakoshi at Tapeswary $(90 \mathrm{~m})$ of Beluri Village Development Committee (VDC) of Saptari District, Nepal. 


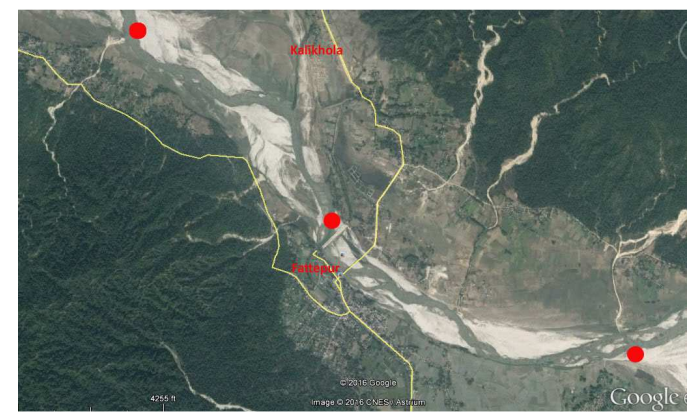

Figure 1. Map of Triyuga River showing study areas.

Fish are members of a paraphyletic group of organism that consists of all gills bearing aquatic craniates which lack limbs with digits. It includes living hag fish, lampreys and cartilaginous and bony fish. Most fish are ectothermic. They are considered as an important natural food resource, worldwide, especially that of animal protein. In Nepal, only bony fishes are there.

As regards to the information of ichthyofauna of Nepal, the contributive works of Berg (1947), De Witt (1962), Shrivastava (1968), Thapa and Rajbanshi (1968), Majumdar et al. (1972), Shrestha (1981), Edds (1986), Shrestha (1990), Shrestha (1994), Talwar and Jhingran (1991), Subba (1995), Subba and Ghosh (1996), Bhagat (1998), Shrestha (2001), and Shrestha (2008) deserve special mention.

The rivers of Nepal are really rich in fish fauna which need to be explored scientifically and conserved them. An attempt, therefore, has been made to conduct a thorough survey of fish diversity of Triyuga River.

\section{Materials and methods}

Fish catching sites in the river were selected. The main fishing sites of the river were regularly visited. The study area was divided into three sites namely (the study area $1^{\text {st }}$ Fattepur) around the weir across the river. The $2^{\text {nd }}$ and $3^{\text {rd }}$ were $3.0 \mathrm{~km}$ above Fattepur i.e., towards upstream and $3.0 \mathrm{~km}$ towards the Saptakoshi i.e., downstream (Fig. 1). Fishes from each fishing site were collected with the help of local fishermen for one year from March 1994 to February 1995. Local made fish traps, fishing nets were used to catch the fishes. Small fishes which were hard to collect by means of fishing tools, so diversions of the course of the river was done at some places. Colour and habitats of fishes were recorded at the time of collection. Photoraphs of fishes were taken before preserving them in formalin. Fishes were, at first, preserved in $40 \%$ formalin for eight hours then in $8 \%$ formalin making their head upside down so as to protect the caudal fin. To prevent natural color from fading, some fishes were preserved in $70 \%$ alcohol. Large fishes were incised longitudinally along their abdomen so that their gut might not get decayed. The morphometric as well as meristic studies of preserved fishes were done with the help of the methods adopted by Mishra (1976) and Shrivastava (1968). Then the fishes were kept in separate containers with tags and labels. The system of classification after Berg (1947) was followed to classify the fishes. The fishes have been kept in the Department of Zoology of Post Graduate Campus, Biratnagar, after their proper identification and classification.

In 2015 the river was resurveyed during two seasons (winter and summer) following the same method mentioned above to know whether any changes have taken place in fish diversity. 


\section{Results and discussion}

The present list includes 48 species belonging to 35 genera, 17 families of 6 orders (Tab. 1; Plate figures). It is interesting to note that fishes of upstream and that of downstream showed distinguishing characters except a few species which migrate up and down. However, there lies every chance of over-lapping in fish habitat, which is difficult to be demarcated sharply. Some of the remarkable fish species of Triyuga River were Barilus shacra, Garra annandalei, Psilorhynchoides pseudecheneis, Badis badis, Olyra longicoudata, Tor putitora, Labeo dero, Anguilla bengalensis etc. The river also has some threatened species (vulnerable species) like Psilorhynchoides pseudecheneis and Anguilla bengalensis. Some species of fishes showed migratory behavior whereas other did not. Migrants were Tor putitora, Barilius barna, Rasbora daniconius, and Anguilla bengalensis. Common and resident species include $L e$ pidocephalichthyes guntea, Somileptes gongata, Ompok bimaculata, Wallago attu, Mystus spp, Channa spp, Macrognathus aral, Glossogobius giuris and Mastacembelus spp.

In the latest survey Chagunius chagunio, Labeo coeruleus, Osteobrama corio cortio, Barilius guttatus, Danio dangila, Esomus dandricus, Chela laubuca and Olyra longicaudata could not be recorded. It might be due to over fishing, poisoning or habitat loss. Number of fish species belonging to each order and conservation status of each species are listed (Tab. 1).

The conservation status of the fishes is 35 common, 4 fairly common, 2 uncommon, 3 vulnerable, 3 occasional and 1 rare (Fig. 2).

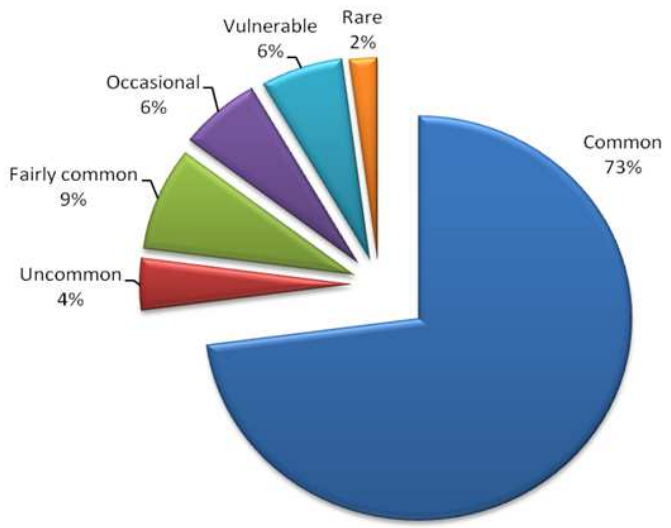

Figure 2. Percentage of conservation status of fishes.

Occurrence of Cyprinidae in Triyuga River as dominant species (23) favours the result of Nepal (Shrestha, 2008; 2013; Rajbanshi, 2012). They reported 86 Cyprinidae (Shrestha, 2008), 18 Balitoridae, 12 Bagridae, 11 Cobitidae, 9 Schilbeidae and 6 Psilorhynchidae. The report of fish species made by Shrestha, (2013) from Nepal also includes fish species reported in the present survey. Families Olyridae, Belonidae, Gobiidae and Synbranchidae were represented by single species in this study as well as in the report made by Shrestha (2008) and Shrestha (2013). None fish species belonging to families Clupeidae, Notopteridae, Moringuidae, Amblycipitidae, Pangasiidae, Siroridae, Chacidae, Heteropneustidae, Clariidae, Hemiramphidae, Poecilidae, Aplocheilidae, Nandidae, Anabantidae, Gobioidiae, Mugilidae, and Tetraodontidae were recorded from Triyuga River. Fishes Aspidoparia jaya, Psilorhynchus sucatio, Labeo caeruleus, Olyra longicaudata, Barilius bola, Barilius shacra, Barilius guttatus and Chela laubuca which were not reported from Narayani River (Jha and Bhujel, 2014) but they were found in Triyuga Riv- 
Table 1. Check list of fishes found in Triyuga River.

\begin{tabular}{|c|c|c|c|c|}
\hline \multirow{2}{*}{\multicolumn{2}{|c|}{ S.N. Scientific name }} & \multirow[t]{2}{*}{ Local name } & \multirow[t]{2}{*}{ English name } & \multirow[t]{2}{*}{ Cons. stat. } \\
\hline & r: Cypriniformes, Family: Cyprinidae & & & \\
\hline 1 & Chagunius chagunio (Ham.-Buch.) 1822 & Rewa, patherchatta & - & $\begin{array}{l}\text { Fairly Com- } \\
\text { mon }\end{array}$ \\
\hline 2 & Labeo caeruleus (Day) 1878 & Rohu & - & Common \\
\hline 3 & Labeo dero (Ham.-Buch.) 1822 & Pausi/Gardi & - & Common \\
\hline 4 & Osteobrama cotio cotio (Ham.-Buch.) 1822 & Gardha & Cotio & Common \\
\hline 5 & Puntius conchonius (Ham.-Buch.) 1822 & Sidra & Stigma barb & Common \\
\hline 6 & Puntius sophore (Ham.-Buch.) 1822 & Poti & Stigma barb & Common \\
\hline 7 & Puntius ticto (Ham.-Buch.) 1822 & Poti & Five fine barb & Common \\
\hline 8 & Tor putitora (Ham.-Buch.) 1822 & Sahar & Mahaseer & $\begin{array}{l}\text { Fairly Com- } \\
\text { mon }\end{array}$ \\
\hline 9 & Aspidoparia jaya (Ham.-Buch.) 1822 & Soli & Aspidoparia & Common \\
\hline 10 & Barilius barna (Ham.-Buch.) 1822 & Phoktahi & Hill trout & Common \\
\hline 11 & Barilius bendelisis (Ham.-Buch.) 1822 & Poksa/tile & Hill trout & Common \\
\hline 12 & Barilius bola (Ham.-Buch.) 1822 & Goha & Hill trout & $\begin{array}{l}\text { Fairly Com- } \\
\text { mon }\end{array}$ \\
\hline 13 & Barilius shacra (Ham.-Buch.) 1822 & Harka & Hill trout & Uncommon \\
\hline 14 & Barilius vagra (Ham.-Buch.) 1822 & Chelhi & Hill trout & Common \\
\hline 15 & Barilius guttatus (Day) 1869 & Jalkapoor & Hill trout & Vulnerable \\
\hline 16 & Danio dangila (Ham.-Buch.) 1822 & - & Danio & Uncommon \\
\hline 17 & Danio devario (Ham.-Buch.) 1822 & Chitari pothi & Danio & Common \\
\hline 18 & Esomus danricus (Ham.-Buch.) 1822 & Deduwa & Flying barb & Common \\
\hline 19 & Rasbora daniconius (Ham.-Buch.) 1822 & Deduwa & Common rasbora & $\begin{array}{l}\text { Fairly Com- } \\
\text { mon }\end{array}$ \\
\hline 20 & Chela laubuca (Ham.-Buch.) 1822 & Deduwa & Winges rasbora & Common \\
\hline 21 & Salmostoma bacaila (Ham.-Buch.) 1822 & Chalwa & - & Common \\
\hline 22 & Garra annandalei Hora 1921 & Budhuna & Stone sucker & Common \\
\hline 23 & Garra gotyla gotyla (Gray) 1832 & Budhuna & Stone sucker & Common \\
\hline \multicolumn{5}{|c|}{ Family: Psilorhynchidae } \\
\hline 24 & Psilorhynchus sucatio (Ham.-Buch.) 1822 & Pathar chatta & - & Occasional \\
\hline 25 & $\begin{array}{l}\text { Psilorhynchoides pseudecheneis (Menon and } \\
\text { Datta) } 1961\end{array}$ & Tite machha & - & vulnerable \\
\hline \multicolumn{5}{|c|}{ Family: Balitoridae } \\
\hline 26 & Acanthocobitis botia (Ham.-Buch.) 1822 & Golheni lata & - & Common \\
\hline \multicolumn{5}{|c|}{ Family: Cobitidae } \\
\hline 27 & Botia lohachata Chaudhari 1912 & Bhage latta & Loach & Common \\
\hline
\end{tabular}


28 Lepidocephalus guntae (Ham.-Buch.) 1822

29 Somileptes gongota (Ham.-Buch.) 1822

Order: Angulliformes, Family: Anguillidae

30 Anguilla bengalensis (Gray and Hardwicke) 1933- Rajbam 34

Order: Siluriformes, Family: Bagridae

\begin{tabular}{|c|c|c|c|c|}
\hline 31 & Mystus bleekeri (Day) 1978 & Tengara & - & Common \\
\hline 32 & Mystus cavasius (Ham.-Buch.) 1822 & Tenagra & Dwarf catfish & Common \\
\hline \multicolumn{5}{|c|}{ Family: Siluridae } \\
\hline 33 & Ompok bimaculatus (Bloch) 1797 & Pabata & Butter cat fish & Common \\
\hline 34 & Wallago attu (Schneider) 1801 & Buhari & Fresh water shark & Common \\
\hline \multicolumn{5}{|c|}{ Family: Schilbeidae } \\
\hline 35 & Pseudeutropius atherinoids Bloch 1794 & Patasi & - & Occasional \\
\hline \multicolumn{5}{|c|}{ Family: Olyridae } \\
\hline & Olyra longicaudata McClelland 1842 & - & - & Rare \\
\hline
\end{tabular}

Order: Beloniformes, Family: Belonidae

37 Xenentodon cancila (Ham.-Buch.) 1822

Kauwa machha

Common

Order: Perciformes, Family: Channidae

38 Channa orientalis Bloch and Schneider 1801

Chenga

Hile

Common

39 Channa punctatus (Bloch) 1793

Green snake headed Common fish

Family: Chandidae

40 Chanda nama (Ham.-Buch.) 1822

Chuna

Classy perchief

Common

41 Parambassis ranga (Ham.-Buch.) 1822

Chuna

Badis

Common

\begin{tabular}{|c|c|c|c|c|}
\hline \multicolumn{5}{|c|}{ Family: Sciaenidae } \\
\hline 42 & Badis badis (Ham.-Buch.) 1822 & - & Badis & Common \\
\hline \multicolumn{5}{|c|}{ Family: Belontidae } \\
\hline 43 & Colisa fasciatus (Schneider) 1801 & Khesara & Banded colisa & Common \\
\hline \multicolumn{5}{|c|}{ Family: Gobiidae } \\
\hline 44 & Glossogobius giuris (Ham.-Buch.) 1822 & Bulla & Bar-eyed gody & Common \\
\hline \multicolumn{5}{|c|}{ Order: Synbranchiformes, Family: Synbranchidae } \\
\hline 45 & Monopterus cuchia (Ham.-Buch.) 1822 & Cuchia bam & $\begin{array}{l}\text { Fresh water eel } \\
\text { cuchia }\end{array}$ & Common \\
\hline \multicolumn{5}{|c|}{ Family: Mastacembelidae } \\
\hline 46 & Macrognathus aral (Bloch and schneider) 1822 & Gainchi & Lesser spiny eel & Common \\
\hline 47 & Macrognathus pancalus (Ham.-Buch.) 1822 & Kath gainchi & - & Common \\
\hline 48 & Mastacembelus armatus (Lacepede) 1800 & Chucchae & Ban spiny eel & Common \\
\hline
\end{tabular}



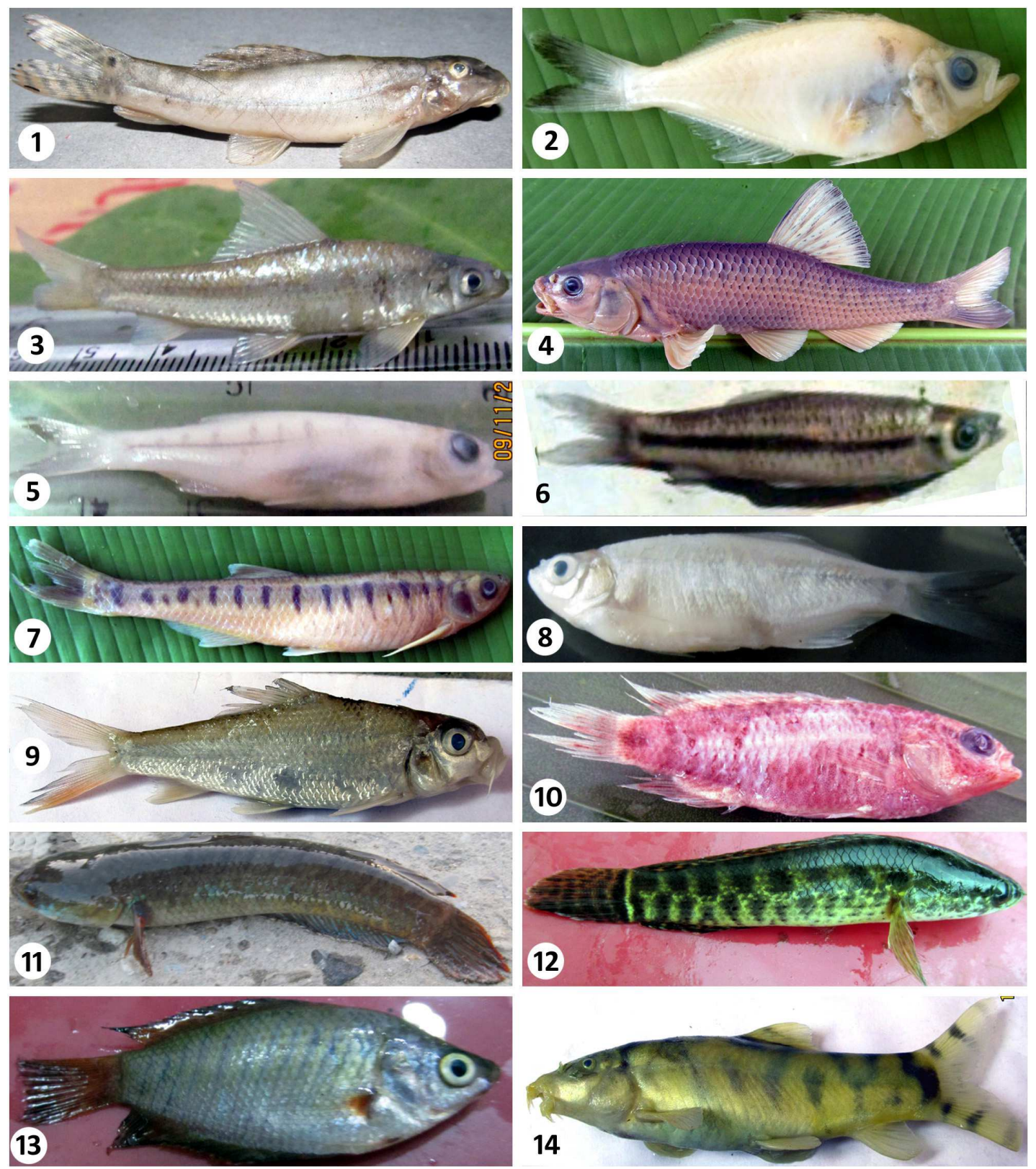

Plate figures: 1. Acanthocobitis botia, 2. Chanda nama, 3. Aspidoparia jaya, 4. Barilius bendelisis,

5. Barilius barna, 6. Rasbora daniconius, 7. Barilius vagra, 8. Danio devario, 9. Chagunius chagunio,

10. Badis badis, 11. Channa orientalis, 12. Channa punctatus, 13. Colisa fasciatus, 14. Botia lohachata. 


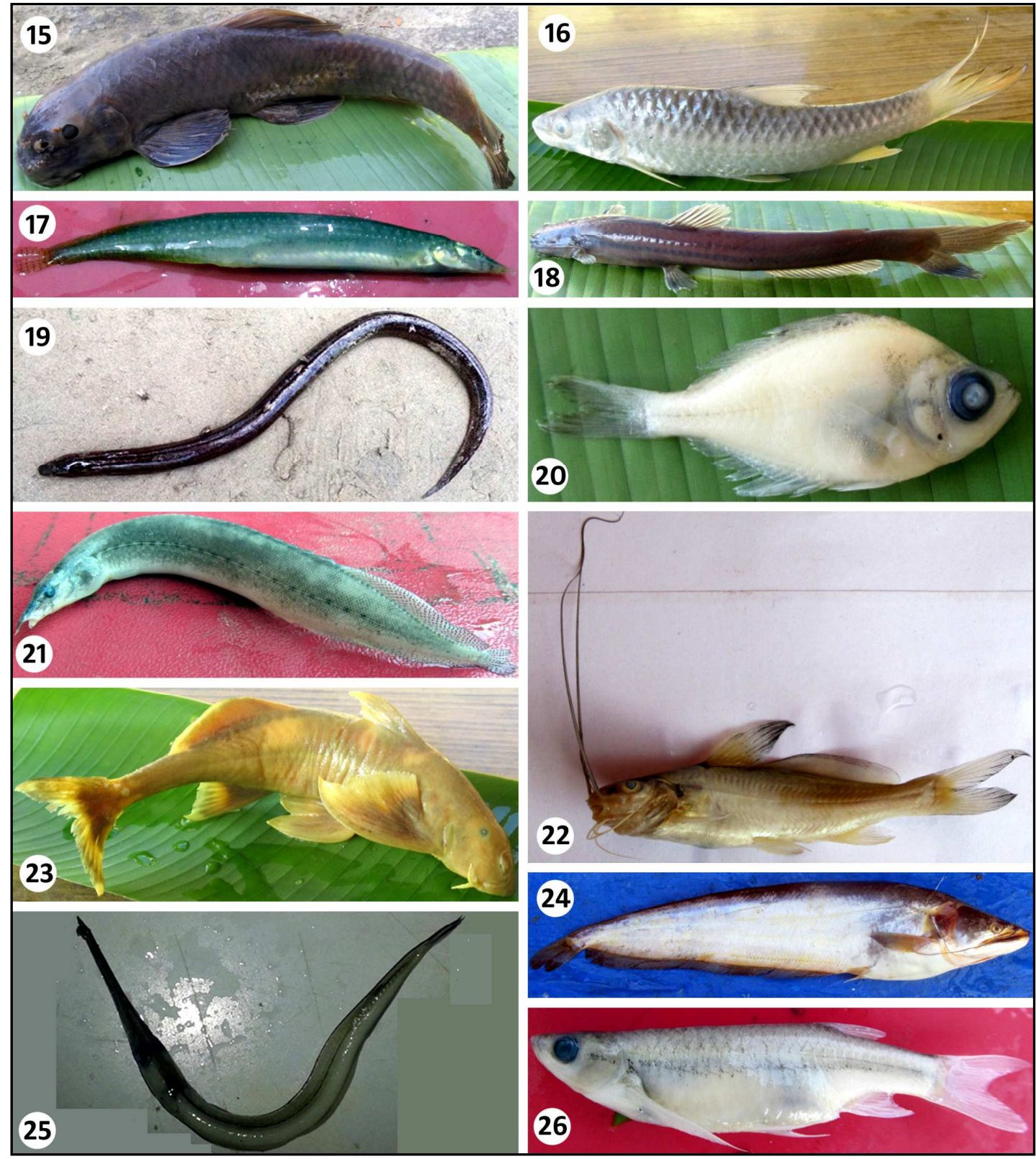

Figures: 15. Garra gotyla gotyla, 16. Tor putitora, 17. Macrognathus pancalus, 18. Olyra longicaudata, 19. Monopterus cuchia, 20. Parambassis ranga, 21 Macrognathus aral, 22. Mystus cavasius, 23. Psilorhynchus sucatio, 24 Wallago attu, 25. Xenentodon cancila, 26. Esomus danricus. 
Shrestha / Our Nature (2016), 14 (1): 124-134

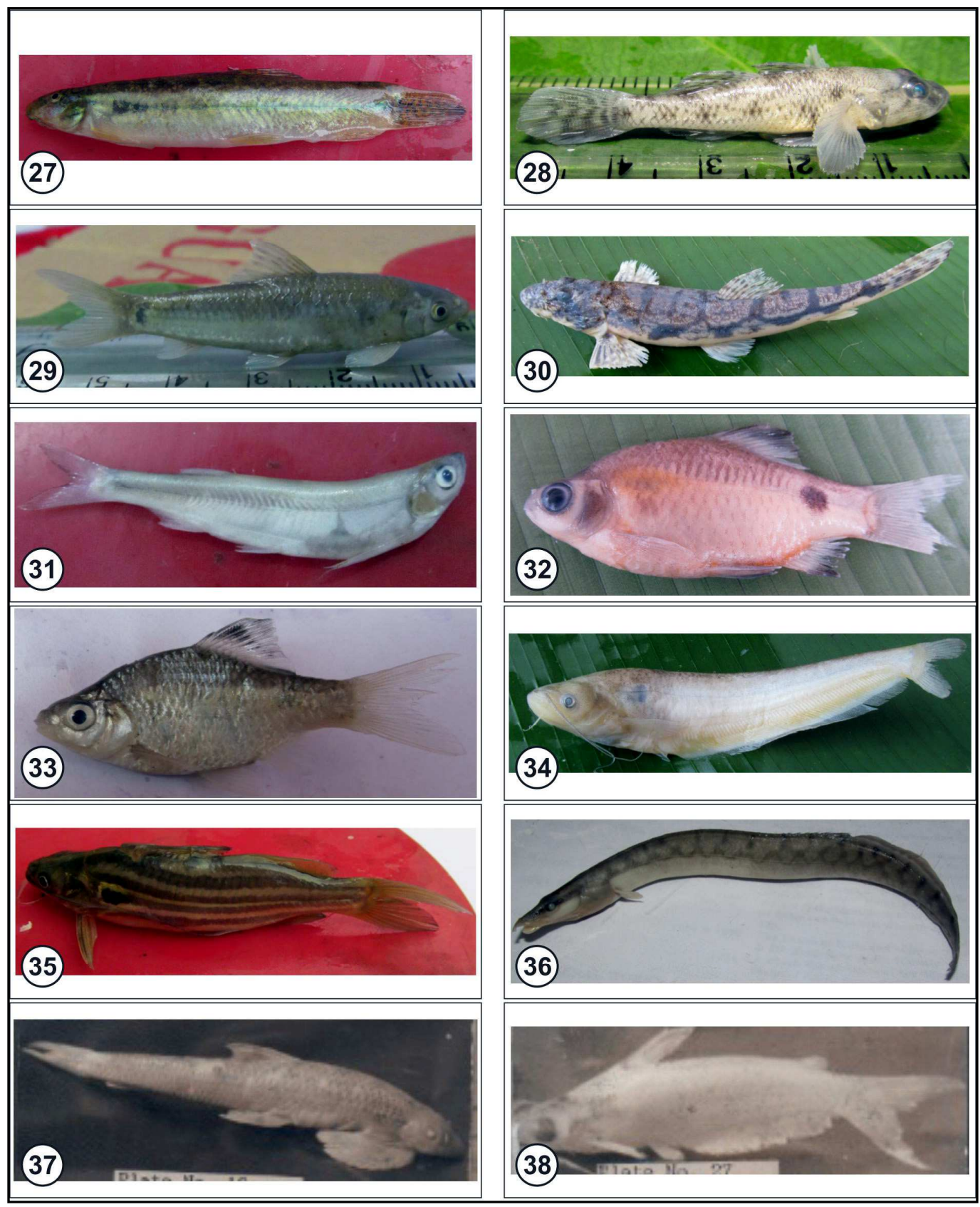

Figures: 27. Lepidocephalus guntae, 28. Glossogobius giuris, 29. Garra annandalei, 30. Somileptes gongota, 31. Salmostoma bacaila, 32. Puntius ticto, 33. Puntius sophore, 34. Ompok bimaculatus, 35. Mystus bleekeri, 36. Mastacembelus armatus, 37. Psilorhynchoides pseudecheneis, 38. Pseudeutropius atherinoids. 
er. Similarly, Anguilla bengalensis, Chela laubuca, Esomus danricus, Osteobrama cotio cotio, Labeo dero, Labeo caeruleus and Pseudeutropius atherinoides which were not reported from Koshi River (Rijal et al. 2014) were reported in the present study. All fish species reported in this study from Triyuga River also have been reported from the Koshi River (Rajbanshi, 2012).

Chagunius chagunio, Puntius conchonius, Puntius sophore, Puntius ticto, Tor putitora, Aspidoparia jaya, Barilius barna, Barilius bendelisis, Barilius bola, Danio devario, Esomus danricus, Chela laubuca, Acanthocobitis botia, Lepidocephalus guntae, Somileptes gongota, Anguilla bengalensis, Mystus bleekeri, Mystus cavasius, Ompok bimaculatus, Wallago attu, Pseudeutropius atherinoids, Xenentodon cancila, Channa orientalis, Channa punctatus, Chanda nama, Parambassis ranga, Colisa fasciatus, Glossogobius giuris, Macrognathus aral and Mastacembelus armatus were found in Triyuga River as well as in Koshi Tappu Wildlife Reserve but Labeo caeruleus, Labeo dero and Osteobrama cotio cotio, Barilius shacra, Barilius vagra, Barilius guttatus, Danio dangila, Rasbora daniconius, Salmostoma bacaila, Garra annandalei, Garra gotyla gotyla, Psilorhynchus sucatio, Psilorhynchoides pseudecheneis, Botia lohachata, Olyra longicaudata, Badis badis, Monopterus cuchia, and Macrognathus pancalus recorded in the present study were not reported (Subba and Limbu, 2009).

\section{Conclusion}

Triyuga River is rich in fish diversity. The present study includes 48 fish species belonging to 35 genera, 17 families and 6 orders. Some of the remarkable fish species are Barilus shacra, Garra annandalei, Psilorhynchoides pseudecheneis, Badis badis, Olyra longicoudata, Tor putitora, Labeo dero, Anguilla bengalensis etc. The river also has some migratory fishes (Anguilla bengalensis, Barilius guttatus and Psilorhynchoides pseudecheneis) which are threatened species (vulnerable species) to Nepal. The river is rich in fish resources and more ecologically important. Further detailed survey of fishes of Triyuga River is recommended for the conservation of threatened fish species.

\section{Acknowledgements}

I would like to thank Prof. Dr. Ram Bahadur Thapa for valuable suggestions and encouragement during my work. I also thank Prof. Dr. D. Thapa Chhetry, Head, Department of Zoology, P.G. Campus for laboratory facilities.

\section{References}

APHA 1998. Standard methods for the examination of water and wastewater (20 ${ }^{\text {th }}$ ed.). American Public Health Association; American Water Work Association and Water Environmental Federation, NW Washington, DC. 153p.

Berg, L.S. 1947. Classification of fishes both recent and fossils (English and Russian). Edwards Brothers, inc. Ann. Arbor. Michigan, U.S.A. pp. 246-517.

Bhagat, R.P. 1998. Fishes from Morang District of Eastern Nepal. J. Nat. Hist. Mus. 17(1-4): 31-38.

De Witt, H.H. 1962. A contribution to the ichthyology of Nepal. Stanford Ichthyological Bulletin 7(4): 63-68.

Edds, D.R. 1986. Fishes of Kali Gandaki/Narayani Rivers. J. Nat. Hist. Mus. 10: 13-22.

Jha, D.K. and R.C. Bhujel 2014. Fish diversity of Narayani River System in Nepal. Nepalese Journal of Aquaculture and Fisheries. 1: 94-108.

Majumdar, N.N., T.C. Majupuria and J. Shrestha 1972. New records from Nepal. J. Zool. Soc., India 2: 213-215. Mishra, K.S. 1976. The fauna of 
India and the adjacent countries. Pisces Vol. 3: Teleostomi;

Cypriniformes; Siluri-2. Zoological Survey of India, Delhi. 367 p.

Rajbanshi, K.G. 2012. Bio-diversity and distribution of fresh water fishes of Central/Nepal Himalayan Region. Nepalese Journal of Aquaculture and Fisheries. The Journal of NEFIS. 136p.

Rijal, P.K., M.K. Shrestha, A.K. Singh and B.R. Dahal 2014. Fish diversity and their contribution in livelihoods of fishers' in Koshi River basin. Nepalese Journal of Aquaculture and Fisheries. The Journal of NEFIS. 1: 109-123.

Shrestha, J. 1981. Fishes of Nepal. Curriculum Development Centre, T.U., Kathmandu, Nepal.

Shrestha, J. 1994. Fishes, fishing implements and methods of Nepal. Smt. M.D. Gupta, Lalitpur Colony, Lashkar (Gwalior) India. 150p.

Shrestha, J. 2001. Taxonomic revision of Fishes of Nepal. In Environment and Agriculture: Biodiversity, Agriculture and Pollution in South Asia (Jha, P.K., S.R. Baral, S.B. Karmacharya, H.D. Lekhak, P. Lacoul and C.B. Baniya eds.), ECOS, Kathmandu. pp. 171-180.

Shrestha, J. 2013. Biodiversity: Fish. In Biological Diversity and Conservatio. (Jha, P.K., F.P. Neupane, M.L. Shrestha and I.P. Khanal eds.), Nepal Academy of Science and Technology, Khumaltar, Lalitpur. pp. 69-81.
Shrestha, T.K. 1990. Resource ecology of the Himalayan waters. Curriculum Development Centre, Tribhuvan University, Kathmandu, Nepal

Shrestha, T.K. 2008. Ichthyology of Nepal: a study of fishes of the Himalayan waters. Himalayan Ecosphere, Kathmandu. 390 p.

Shrivastava, G. 1968. Fishes of eastern U.P. Vishwavidyalaya Prakashn, Varanasi, India. 163 p.

Subba, B.R. 1995. Report on the occurrence of a hill stream fish, Olyra longicaudata (McClelland, 1842), Siluriformes, Olyridae from Kadya River of Nepal. Journal of Freshwater Biology 7: 155157.

Subba, B.R. and J.K. Ghosh 1996. A new record of the pigmy barb Puntius phutunio (Ham.) from Nepal. Journla of Freshwater Biology 8(3): 159161.

Subba, B.R. and K.P. Limbu 2009. Biodiversity assessment of Koshi Tappu Wildlife Reserve after Koshi flood disaster 2008. Final report submitted to WWF Nepal and CEPF.

Talwar, P.K. and A.G. Jhingran 1991. Inland fishes of India and adjacent Countries. Vol. I and II, Oxford and IBH Publishing Co. New Delhi, India.

Thapa, R.B. and K.G. Rajbanshi 1968. Report on few Hill-stream fishes in Nepal. Regional Seminar on Ecology of Tropical Highland, UNESCO/HMG, Kathmandu,Nepal. 